\title{
$\nabla$ \\ Awareness of COVID-19 Among South Indian Population
}

\section{IJCRR}

Section: Healthcare

Sci. Journal Impact

Factor: 6.1 (2018)

ICV: 90.90 (2018)

(c) (i) (8)

Copyright@IJCRR

\section{Surya C' ${ }^{1}$ Leslie Rani², R Gayatri Devi ${ }^{3}$}

'Saveetha Dental College and Hospital, Saveetha Institute of Medical and Technical Sciences, Saveetha University, Chennai, India; ${ }^{2} L e c t u r e r$, Department of Pathology, Saveetha Dental College and Hospital, Saveetha Institute of Medical and Technical Sciences, Saveetha University, Chennai, India; ${ }^{3 A s s i s t a n t ~ P r o f e s s o r, ~ D e p a r t m e n t ~ o f ~ P h y s i o l o g y, ~ S a v e e t h a ~ D e n t a l ~ C o l l e g e ~ a n d ~ H o s p i t a l, ~ S a v e e t h a ~ I n s t i t u t e ~ o f ~ M e d i c a l ~ a n d ~ T e c h n i-~}$ cal Sciences, Saveetha University, Chennai, India.

\section{ABSTRACT}

Aim: The aim of the study is to create an awareness level of COVID-19 among the South Indian population.

Introduction: COVID-19 was first identified in Wuhan, the capital of China in December, 2019. It is the viral type of infection that causes respiratory problems in humans. Common symptoms of coronavirus are fever, cough, and shortness of breathing. Symptoms of coronavirus may also include muscle pain, diarrhea, and sore throat, loss of smell, fatigue, and sometimes abdominal pain.

Materials and Method: A 15 cross-sectional questionnaire was conducted among 100 south Indian populations during May 2020. 15 self-prepared questions were based on the demographic details of respondents and questions to assess the awareness on COVID-19, its symptoms, mode of transmission, and its prevention. All the questions are formulated using "Google forms" as multiple choice questions with the link.

Result: Most of the people are aware of common symptoms of COVID-19. $90 \%$ of the people are aware of the incubation period, and $67 \%$ of people are aware of the preventive measures.

Conclusion: From this survey, it is evident that the most of the south Indian population was aware of the causes, risk factors, mode of transmission, incubation period, home remedies, and treatment for coronavirus..

Key Words: Coronavirus, COVID-19, Wuhan, Mask, China, Pandemic, Awareness.

\section{INTRODUCTION}

Coronavirus disease-2019 is an infectious disease caused by severe acute respiratory syndrome coronavirus- 2 . The disease was first identified in December, 2019 in Wuhan, capital of China ${ }^{1}$. Common symptoms of coronavirus are fever, cough, and shortness of breathing ${ }^{2}$. Other symptoms may include fatigue, muscle pain, diarrhea, sore throat, loss of smell, and abdominal pain ${ }^{3}$. The incubation time for coronavirus inside the human body is about 1 to 14 days ${ }^{4}$. Coronaviruses are RNA viruses. The name "coronavirus" is derived from the Latin word "Corona" meaning "crown". The name was coined by June Almeida and David Tyrrell who first observed and studied human coronavirus. Coronavirus was first discovered in 1930 in the name of the infectious bronchitis virus from domesticated chickens ${ }^{6}$. In 1940, two more coronaviruses namely mouse hepatitis virus and transmissible gastroenteritis virus were isolated.
It was not realized at that time that these three different viruses were related ${ }^{7}$.

Coronavirus mainly targets epithelial cells. Human coronavirus infects epithelial cells of the respiratory tract while animal coronavirus generally infects epithelial cells of the digestive tract ${ }^{8}$. The human coronavirus has a $96 \%$ similarity to bat coronavirus so it is widely suspected to originate from bats as well ${ }^{9}$. The pandemic results in travel restrictions and nationwide lockdown in several countries. There is a critical requirement for viable treatment. The current spotlight has been on the advancement of novel therapeutics, including antivirals and antibodies ${ }^{10}$. In the course of the most recent a while, the coronavirus 2019 (COVID-19) flare-up has quickly developed to become a worldwide pandemic. Nations, areas, and territories have fluctuated and in numerous cases, exceptional ways to deal with limit the effect of COVID-19.

\section{Corresponding Author:}

Dr. Lesli Rani, Lecturer, Department of Pathology, Saveetha Dental College and Hospital, Saveetha Institute of Medical and Technical Sciences, Saveetha University, Chennai, India; Phone: 9360293308; Email: leslieranis.sdc@saveetha.com

ISSN: 2231-2196 (Print)

Received: 26.07 .2020
ISSN: 0975-5241 (Online)

Revised: 23.08 .2020
Accepted: 28.09 .2020
Published: 20.10 .2020 
The media has been announcing ceaselessly across the outskirts to keep all educated about the pandemic circumstance $^{11}$. Every one of these things is making a great deal of worry for individuals prompting uplifted degrees of nervousness. Before, the severe acute respiratory syndrome Coronavirus (SARS-CoV) and the Middle East respiratory condition coronavirus (MERS-CoV) have been known to influence people. Flare-ups of respiratory illness brought about by these infections appear to have started in creatures before moving into different hosts like people. MERS-CoV was seen as transmitted from Arabian camels to people, while SARS-CoV was transmitted from civet cats to peo$\mathrm{ple}^{12}$.

We can reduce the spread of COVID-19 coronavirus by following the guides given by $\mathrm{WHO}^{13}$. Regularly clean your hands with hand sanitizer and soap to reduce the spread of infection. Maintain a distance of at least 1 metre from others to reduce the spread of infection. Avoid crowded places like public gatherings to prevent the spread of infection. Wash your hand before touching eyes, nose, ears because it may contain a virus that will enter the body and cause disease ${ }^{14,15}$. Staying at home and isolation will reduce the spread of viruses because avoiding contact with others will protect them from possible COVID-19 and other viruses.

\section{MATERIALS AND METHODS}

A 15 cross-sectional questionnaire was conducted among 100 south Indian populations during May, 2020. 15 selfprepared questions were based on the demographic details of respondents and questions to assess the awareness of COVID-19, its symptoms, mode of transmission, and its prevention. All the questions are formulated using "Google forms" as multiple choice questions with the link. https://docs.google.com/forms/d/1XMNrmEqx8aeqWqj VDh1uHdAy7-YBhilbPckCHeh9i-o/edit?chromeless=1. Data was coded in the "Microsoft excel sheet" and entered into SPSS software. The results are depicted in the form of pie charts.

\section{STATISTICAL ANALYSIS}

Statistical test used was Chi-square to find the association between the genders and the responses to the questions.

\section{RESULTS AND DISCUSSIONS}

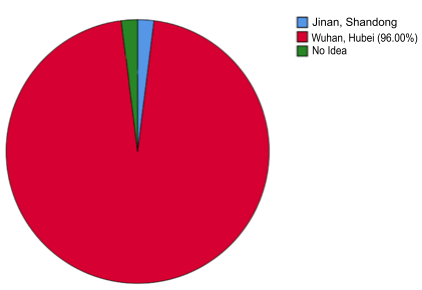

Figure 1: Pie chart represents the knowledge of people about the origin of COVID-19. $2 \%$ of people said in Jining, Shandong, $96 \%$ of people said in Wuhan, Hubei, and $2 \%$ of people have no idea.

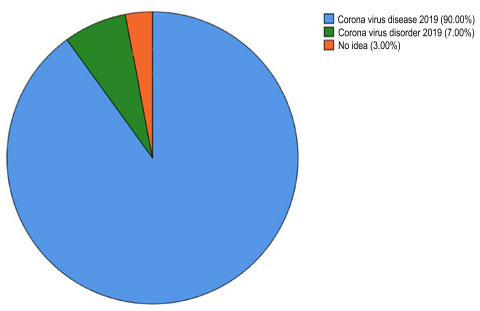

Figure 2: Pie chart represents the knowledge of people about the full form of COVID-19. $90 \%$ of people think the full form of COVID-19 is coronavirus disease $2019,7 \%$ of people think coronavirus disorder 2019 , and $3 \%$ of people have no idea.

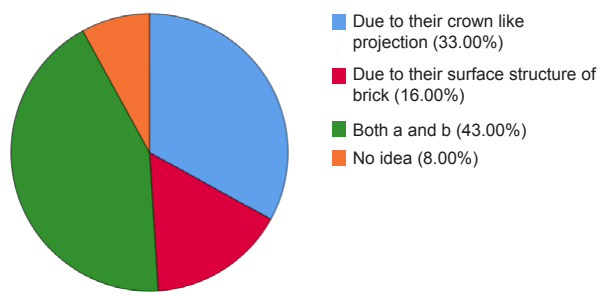

Figure 3: Pie chart represents the knowledge of people about why corona is named so. $33 \%$ of people said the name of the coronavirus is due to their crown-like projection, $16 \%$ of people said due to their surface structure of brick, $43 \%$ of people said both crown-like structure and surface structure of brick, and $8 \%$ of people have no idea.

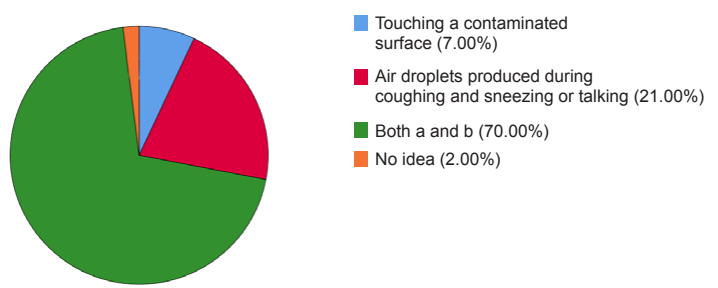

Figure 4: Pie chart awareness on the mode of spread of COVID-19. $7 \%$ of people said people get infected by coronavirus by touching a contaminated surface, $21 \%$ of people said air droplets produced during coughing and sneezing (or) talking, $70 \%$ of people said both contaminated surface and air droplets, and $2 \%$ of people have no idea. 


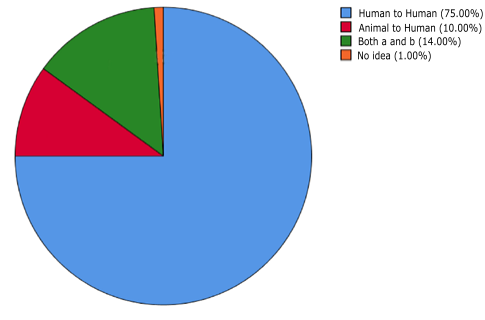

Figure 5: Pie chart represents the awareness of the mode of transmission of COVID-19. $75 \%$ of people said coronavirus transmit through Human to Human, $10 \%$ of people think from Animal to Human, $14 \%$ of people think both from human to human and animal to human, $1 \%$ of people have no idea.

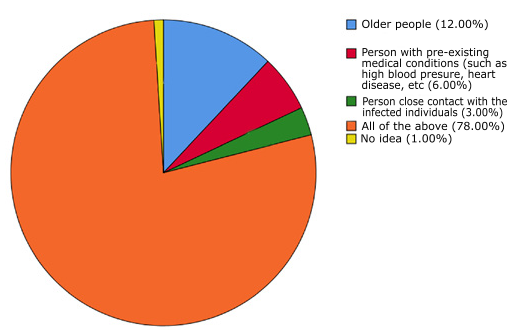

Figure 6: Pie chart represents the awareness of people at high risk to get the infection. $12 \%$ of people think old people are at risk of developing severe illness, $6 \%$ of people think of people with pre-medical conditions, $3 \%$ of people think of close contact with the infected individuals, $78 \%$ of people think all the above and $1 \%$ of people have no idea.

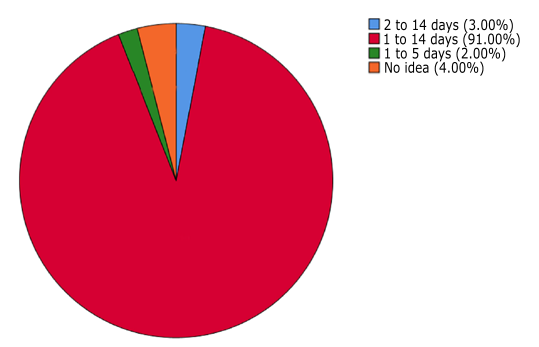

Figure 7: Pie chart represents the awareness of the incubation period of viruses. $3 \%$ of people said 2 to 14 days, $91 \%$ said 1 to 14 days, $2 \%$ said 1 to 5 days, $4 \%$ of people have no idea.

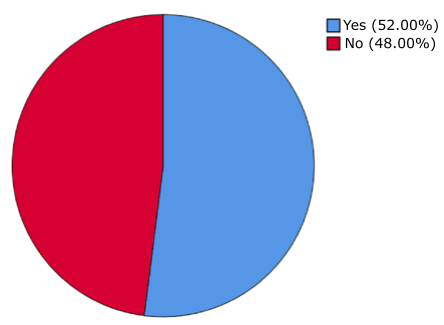

Figure 8: Pie chart represents awareness about home remedies in preventing the spread of disease. $52 \%$ of people said home remedies help in the control of COVID-19 and $48 \%$ of people said No.

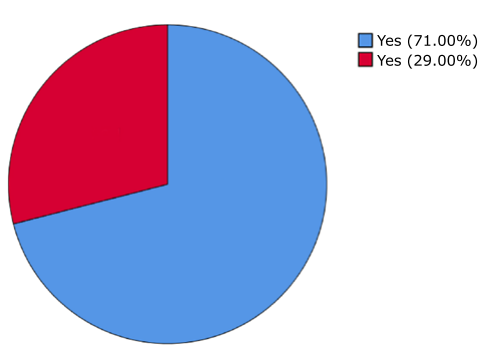

Figure 9: Pie chart represents the awareness of people about the symptoms of Corona. $71 \%$ of people are aware of the symptoms and $29 \%$ are not aware.

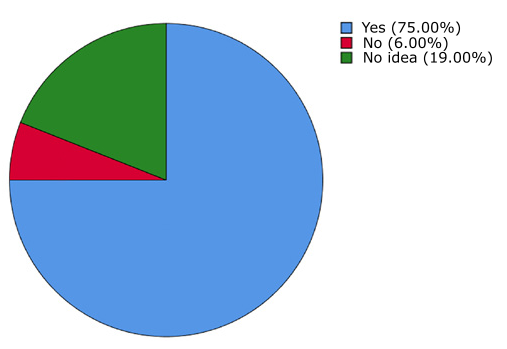

Figure 10: Pie chart represents the awareness about the lockdown. $75 \%$ of people are aware, $6 \%$ are not aware and $19 \%$ said it might help in controlling the spread of the disease.

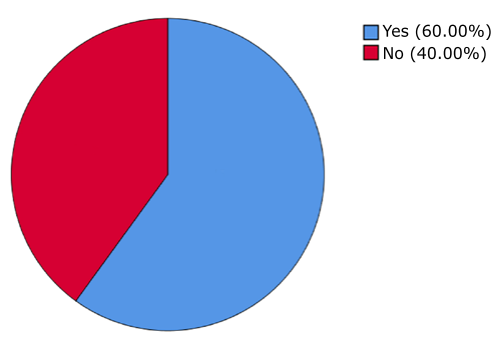

Figure 11: Pie chart represents awareness on the treatment of coronavirus. $60 \%$ of people said there is a treatment for coronavirus, $40 \%$ of people said No.

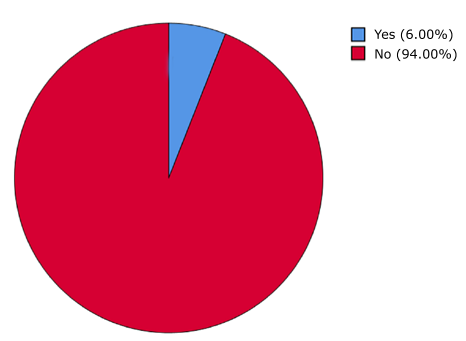

Figure 12: Pie chart represents awareness of people about vaccines for coronavirus. $6 \%$ of people said there is a vaccine for coronavirus, $94 \%$ of people said there is no vaccine. 


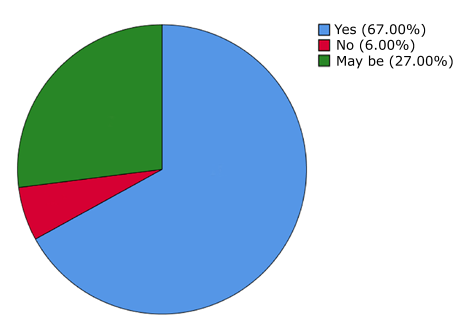

Figure 13: Pie chart represents awareness of people about using masks and handwash hygiene. $67 \%$ of people said mask and hand wash hygiene helps in control COVID-19, $27 \%$ of people said it won't and $6 \%$ of people said they may be useful.

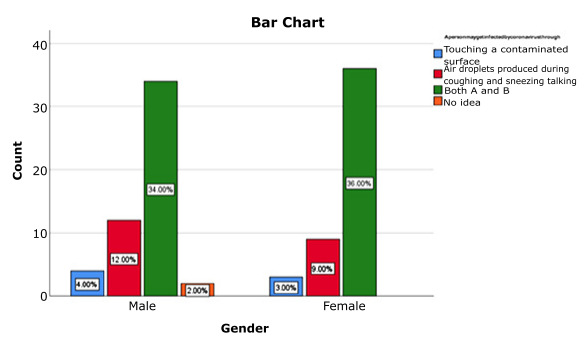

Figure 14: Bar graph represents the association between gender and awareness on the mode of spread of coronavirus infection. X-axis represents the gender and Y-axis represents the number of participants and their response regarding the occurrence of coronavirus. Blue denotes touching a contaminated surface, red denotes air droplets produced during coughing, sneezing, or talking, green denotes both a and b, orange denotes no idea. The majority of females (36\%) are aware of the mode of spread. Pearson's Chi-square value is 2.473 , DF-3, P-value is $0.480(>0.05)$ Hence it is not statistically significant.

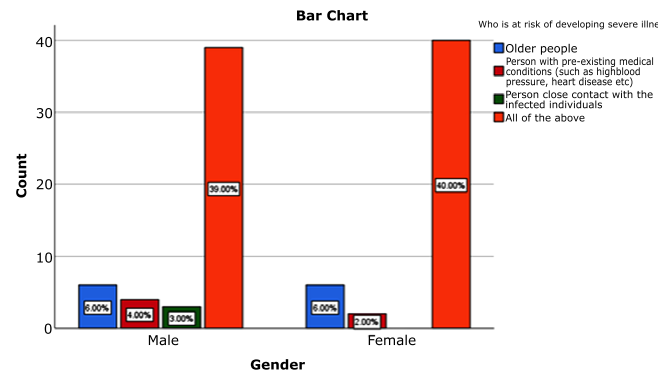

Figure 15: Bar graph represents the association between gender and awareness of higher-risk people. X-axis represents the gender and $\mathrm{Y}$-axis represents the number of participants and their response regarding the risk factors of coronavirus. Blue denotes older people, red denotes a person with pre-existing medical conditions (such as high blood pressure, heart disease, etc.), green denotes person in close contact with the infected individuals, orange denotes all of the above. The majority of females (40\%) are aware that older people, medically compromised people, and people taking care of COVID patients are at high risk. Pearson's Chi-square value: 3.525, DF-3, P-value: $0.318(>0.05)$. Hence, it is not statistically significant.

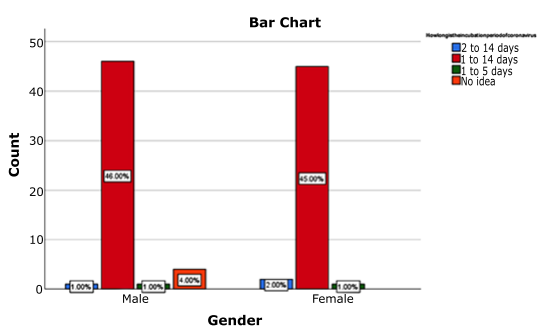

Figure 16: Bar graph represents the association between gender and knowledge of people about the incubation time for coronavirus. $\mathrm{X}$-axis represents the gender and $\mathrm{Y}$-axis represents the number of participants and their response regarding the incubation time of coronavirus. Blue denotes 2 to 14 days, red denotes 1 to 14 days, green denotes 1 to 5 days, orange denotes no idea. The majority of male (46\%) are aware of the incubation period. Pearson's Chi-square value: 4.191, DF-3, P-value: $0.242(>0.05)$ hence it is not statistically significant. .

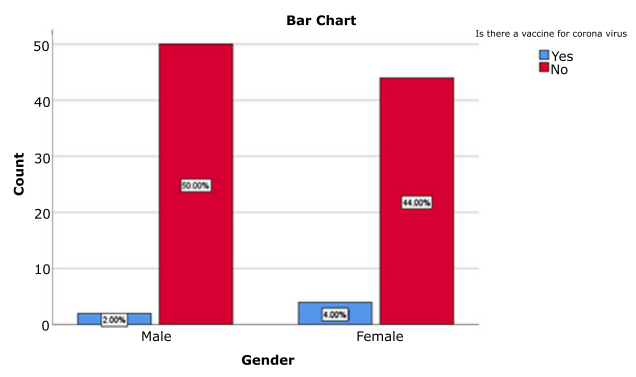

Figure 17: Bar graph represents the association between gender and awareness of people about vaccines for coronavirus infection. X-axis represents the gender and Y-axis represents the number of participants and their response regarding the vaccines for coronavirus. Blue denotes yes and red denotes no. The majority of male (50\%) are aware of vaccination. Pearson's Chi-square value: 0.891 , df-1, P-value: $0.345(>0.05)$. Hence, it is not statistically significant.

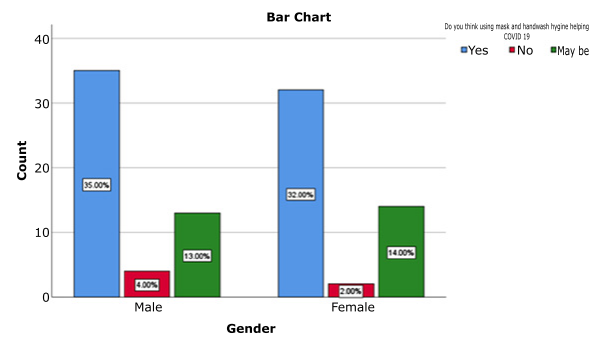

Figure 18: Bar graph represents the association between gender and awareness of people about using masks and hand wash hygiene. $\mathrm{X}$-axis represents the gender and $\mathrm{Y}$-axis represents the number of participants. Blue denotes yes, red denotes no and green denotes maybe. The majority of males (35\%) are aware of using masks and hand wash hygiene. Pearson's Chisquare value: 0.679 , DF-2, P-value: $0.712(>0.05)$. Hence it is not significantly significant. 
Among 100 people, $2 \%$ of people think coronavirus was first identified in Jining, Shandong, $96 \%$ of people think Wuhan, Hubei, and $2 \%$ of people have no idea (Figure 1). Among 100 people, $90 \%$ of people think the full form of COVID-19 is coronavirus disease $2019,7 \%$ of people think coronavirus disorder 2019 and 3\% of people have no idea (Figure 2). Among 100 people, $33 \%$ people think the name of the coronavirus is due to their crown-like projection, $16 \%$ people think due to their surface structure of brick, $43 \%$ people think both crown-like structure and surface structure of brick, and $8 \%$ of people have no idea (Figure 3). Among 100 people, $7 \%$ of people think people get infected by coronavirus by touching a contaminated surface, $21 \%$ of people think air droplets produced during coughing and sneezing (or) talking, $70 \%$ of people think Both contaminated surface and air droplets, and $2 \%$ people have no idea (Figure 4 ). The majority of people say that coronavirus spreads through air ${ }^{16}$. The person gets infected with coronavirus mainly by touching the infected persons and through the air $^{17}$. Among 100 people, $75 \%$ of people think coronavirus transmit through Human to Human, $10 \%$ of people think from Animal to $\mathrm{Hu}-$ man, $14 \%$ of people think both from human to human and animal to human, $1 \%$ people have no idea (Figure 5). Studies say that the virus transmits from both human to human and animal to human ${ }^{18}$.

Among 100 people, $12 \%$ of people think old people are at risk of developing severe illness, $6 \%$ think of people with pre-medical conditions, $3 \%$ of people think of close contact with the infected individuals, $78 \%$ of people think all the above and $1 \%$ of people have no idea (Figure 6). Older people and people with low immunity will easily be affected by coronavirus $^{19}$. Among 100 people, $3 \%$ think 2 to 14 days is the incubation time for coronavirus, $91 \%$ of people think 1 to 14 days, $2 \%$ of people think 1 to 5 days, and $4 \%$ of people have no idea (Figure 7). The incubation time for coronavirus is 1 to 14 days $^{20}$.

If the individual is affected by coronavirus he/she will suffer from high fever, cough, and shortness of breathing ${ }^{21}$. Among 100 people, $52 \%$ people think home remedies help in the control of COVID-19 and 48\% of people think No (Figure 8 ). Home remedies such as ginger, herbal tea help in increasing immunity ${ }^{22}$. Among 100 people, $71 \%$ of people think Fever, dry cough, difficulty in breathing are the confirmatory symptoms of coronavirus, $29 \%$ of people think No (Figure 9). Among 100 people, $75 \%$ of people think lockdown helps in controlling the spread of coronavirus, $6 \%$ of people think No and 19 people think it may help in controlling the spread of coronavirus (Figure 10). Lockdown helps in controlling the spread of coronavirus by maintaining social distancing ${ }^{23}$. The WHO says maintaining social distancing and keeping oneself hygiene helps in preventing the coronavirus ${ }^{24}$.
Among 100 people, $60 \%$ of people think there is a treatment for coronavirus, $40 \%$ of people think No (Figure 11 ). Among 100 people, $6 \%$ of people think there is a vaccine for coronavirus, $94 \%$ of people think No (Figure 12). The majority of people think the pneumonia vaccine cures coronavirus ${ }^{25}$. Among 100 people, $67 \%$ people think mask and hand wash hygiene helps in control COVID-19, 27\% people thinks No and $6 \%$ of people think may be useful (Figure 13). The majority of people think masks are useful in controlling the spread of coronavirus $80 \%$ Yes and $20 \%{ }^{26}$. Until now research is being conducted from the biopsy/smear of buccal lesions of infected people to study the nature of the disease and its genome whether it might cause cystic lesions ${ }^{27,} 28$. There is no significant difference between the gender and knowledge of the spread of coronavirus infection (Figure 14). There is no significant difference between gender and knowledge on risk factors (Figure 15). There is no significant difference between the gender and knowledge of people about the incubation time for coronavirus (Figure 16). There is no significant difference between the gender and knowledge of people about vaccines for coronavirus infection (Figure 17). There is no significant difference between the gender and knowledge of people about using masks and hand wash hygiene (Figure 18).

\section{CONCLUSION}

From this survey, it is evident that most of the south Indian population was aware of the causes, risk factors, mode of transmission, incubation period, home remedies, and treatment for coronavirus. Even though they are aware of COVID-19, the spread of infection increases day by day. In order to flatten the curve, the general public should follow the rules put forth by the government.

\section{ACKNOWLEDGEMENT}

We acknowledge the help offered by the institute, usage of facilities.

\section{Conflict of Interest}

All the authors declare no conflict of interest in the study

\section{Financial Support}

None

\section{REFERENCES}

1. Bhagavathula AS, Aldhaleei WA, Rahmani J, Mahabadi MA, Bandari DK. Knowledge and Perceptions of COVID-19 Among Health Care Workers: Cross-Sectional Study. JMIR Public Health Surveill [Internet]. 2020 Apr 30;6(2):e19160. Available from: http://dx.doi.org/10.2196/19160 
2. Brundha MP, Pathmashri VP. Quantitative Changes of Red Blood cells in Cancer Patients under Palliative RadiotherapyA Retrospective Study. Research Journal of [Internet]. 2019; 12(2): 687-689. Available from: http://www.indianjournals.com/ ijor.aspx?target $=$ ijor:rjpt\&volume $=12 \&$ issue $=2 \&$ article $=041$

3. Roy D, Tripathy S, Kar SK, Sharma N, Verma SK, Kaushal V. Study of knowledge, attitude, anxiety \& perceived mental healthcare need in Indian population during COVID-19 pandemic. Asian J Psychiatr [Internet]. 2020 Apr 8;51:102083. Available from: http://dx.doi.org/10.1016/j.ajp.2020.102083

4. Zhong B-L, Luo W, Li H-M, Zhang Q-Q, Liu X-G, Li W-T, et al. Knowledge, attitudes, and practices towards COVID-19 among Chinese residents during the rapid rise period of the COVID-19 outbreak: a quick online cross-sectional survey [Internet]. International Journal of Biological Sciences. 2020; 16:1745-52. Available from: http://dx.doi.org/10.7150/ijbs.45221

5. Chatterjee P, Nagi N, Agarwal A, Das B, Banerjee S, Sarkar S, Gupta N, Gangakhedkar RR. The 2019 novel coronavirus disease (COVID-19) pandemic: A review of the current evidence. Indian J Med Res 2020;151:147-59

6. Malay KK, Duraisamy R, Brundha MP. Awareness regarding anemia among 1st year dental undergraduate students. Drug Invention [Internet]. 2018; 10(8): 1463- 1467. Available from: http://search.ebscohost.com/login.aspx?direct=true\&profile=eh ost\&scope $=$ site \&authtype $=$ crawler\&jrnl $=09757619 \& A N=1309$ 03213\&h=6IXGXY2FNBcKId5DHNd2dXCfxQJr\%2BzLQ09 XGxxxBIbvGS1xdIHRzzZ6fYcY3h1vs3IDexIiUCaAeQcyAj0 $\mathrm{uKKQ} \% 3 \mathrm{D} \% 3 \mathrm{D} \& \mathrm{crl}=\mathrm{c}$

7. Riad A, Huang Y, Zheng L, Elavsky S. COVID-19 Induced Anxiety and Protective Behaviors During COVID-19 Outbreak: Scale Development and Validation. medRxiv - the preprint server for health science. 2020: 1-10 [Internet]. Available from: http://dx.doi.org/10.1101/2020.05.05.20050419

8. Sarvesh Kumar J, Brundha MP. Awareness about childhood vaccination among parents with children below 15 years of age. Drug Invention Today [Internet]. 2018; 10(12): 2481-2484. Available from: http://search.ebscohost.com/login.aspx?direct $=$ true \&profile $=$ ehost $\&$ scope $=$ site $\&$ authtype $=$ crawler $\& \mathrm{jrnl}=097$ $57619 \& \mathrm{AN}=132447040 \& \mathrm{~h}=2 \mathrm{WpShrfu} \% 2 \mathrm{BS} 1 \mathrm{TcRwVn20QzX}$ QmGi0LTVw8007Sf3e5Ps0hFqxpLBw\%2Fk91HZB\%2FzP\%2 Fw\%2BmIN5YM6Eu4FTDn8aIdinZg\%3D\%3D\&crlc

9. Varshini A, Rani SL, Brundha MP. Awareness of annual doctor checkups among general population. Drug Invention Today. 2020;14(2): 274- 278 .

10. Kumar MDA, Ashok Kumar MD, Brundha MP. Awareness about nocturia-A questionnaire survey [Internet]. Research Journal of Pharmacy and Technology. 2016; 9(11): 1941- 1944. Available from: http://dx.doi.org/10.5958/0974-360x.2016.00344.9

11. Ma J, Jahangir MA, Department of Pharmaceutics, Nibha Institute of Pharmaceutical Sciences, Rajgir, Nalanda-, et al. Coronavirus (COVID-19): History, Current Knowledge and Pipeline Medications [Internet]. International Journal of Pharmaceutics \& Pharmacology. 2020; 4: 140- 149. Available from: http:// dx.doi.org/10.31531/2581-3080.1000140

12. Mp B, Brundha MP, Nallaswamy D. Hide and seek in pathology- A research on game-based histopathology learning [Internet]. International Journal of Research in Pharmaceutical Sciences. 2019; 10 (6): 1410-4. Available from: http://dx.doi. org/10.26452/ijrps.v10i2.606

13. Prashaanthi N, Brundha MP. A Comparative Study between Popplet Notes and Conventional Notes for Learning Pathology [Internet]. Research Journal of Pharmacy and Technology. 2018; 11 (1): 175-178. Available from: http://dx.doi.org/10.5958/0974360x.2018.00032.x
14. Timothy CN, Samyuktha PS, Brundha MP. Dental pulp Stem Cells in Regenerative Medicine - A Literature Review [Internet]. Vol. 12, Research Journal of Pharmacy and Technology. 2019; 12(8): 4052- 4056. Available from: http://dx.doi. org/10.5958/0974-360x.2019.00698.x

15. P Jannathulferdioz BM. Awareness of Stye. Int J Pharm Sci Rev Res. 2016; 40(1):30-2.

16. Gaffar BO, El Tantawi M, Al-Ansari AA, AlAgl AS, Farooqi FA, Almas KM. Knowledge and practices of dentists regarding MERS-CoV. A cross-sectional survey in Saudi Arabia. Saudi Med J [Internet]. 2019;40(7):714-20. Available from: http:// dx.doi.org/10.15537/smj.2019.7.24304

17. Kalaiselvi R, Brundha MP. Prevalence of hysterectomy in South Indian population [Internet]. Vol. 9, Research Journal of Pharmacy and Technology. 2016; 9(11):1941-1944 1941. Available from: http://dx.doi.org/10.5958/0974-360x.2016.00398.x

18. Preethikaa S, Brundha MP. Awareness of diabetes mellitus among general population. J Pharm Res [Internet]. 2018; 11(5): 1825 - 1829 Available from: http://www.indianjournals.com/ ijor.aspx?target $=$ ijor:rjpt $\&$ volume $=11 \&$ issue $=5 \&$ article $=024$

19. Harsha L, Brundha MP. Prevalence of Dental Developmental Anomalies among Men and Women and its Psychological Effect in a Given Population. J. Pharm. Sci. \& Res. 2017: 9(6): 869-873

20. Ravisankar A. Comparative Study of Touch Perception in Normal and Blind People. J Pharm Sci [Internet]. 2016;8(11):1285-87 Available from: http://search.proquest. com/openview/0a88b19f0bdc64d11cc548f4b82f9ff9/1?pqorigsite $=$ gscholar \&cbl $=54977$

21. Ravichandran H, Brundha MP. Awareness about Personal Protective Equipments in Hospital Workers (Sweepers and Cleaners) - J. Pharm. Sci. \& Res. 2016; 40(1):28-29

22. Balaji S, Brundha. MP, Path DNB. Awareness of About Breast Cancer among Dental Surgeons. J. Pharm. Sci. \& Res.2016; 8(8): 797-800

23. Brundha MP. Awareness of Polycystic Ovarian Disease among Females of Age Group 18-30 Years. J. Pharm. Sci. \& Res. 2016: Vol. 8(8): 813-816

24. Brundha MP. A Comparative Study- The Role of Skin and Nerve Biopsy in Hansen's Disease. J. Pharm. Sci. \& Res. 2015; Vol. 7(10): 837-844

25. Modi PD, Nair G, Uppe A, Modi J, Tuppekar B, Gharpure AS, et al. COVID-19 Awareness Among Healthcare Students and Professionals in Mumbai Metropolitan Region: A Questionnaire-Based Survey. Cureus [Internet]. 2020 Apr 2;12(4):e7514. Available from: http://dx.doi.org/10.7759/cureus.7514

26. Pérez-Campos Mayoral L, Mayoral-Andrade G, Pérez-Campos Mayoral E, Hernández-Huerta MT, Pérez-Campos E. A Letter to the Editor on "World Health Organization declares global emergency: A review of the 2019 novel Coronavirus (COVID-19)." Int J Surg [Internet]. 2020 May 27; Available from: http://dx.doi. org/10.1016/j.ijsu.2020.05.066

27. Hannah R, Ramani P, Brundha MP, Herald. J. Sherlin, Ranjith G, Ramasubramanian A, et al. Liquid Paraffin as a Rehydrant for Air Dried Buccal Smear [Internet]. Vol. 12, Research Journal of Pharmacy and Technology. 2019; 12(3): 1197 - 1200. Available from: http://dx.doi.org/10.5958/0974-360x.2019.00199.9

28. William A. M. The Impact of COVID-19 on Residents of Skilled Care Facilities Throughout the United States. Int J Cur Res Rev. Vol 12 Issue 16, August, 2020, 1-1, http://dx.doi.org/10.31782/ IJCRR.2020.121617 


\section{QUESTIONNAIRE}

1. Coronavirus was first identified in?

2. What is the full form of COVID-19?

3. Why the virus is named as corona?

4. A person may get infected by the coronavirus through?

5. Mode of transmission of COVID-19?

6. Who is at risk of developing severe illness?

7. How long is the incubation period of coronavirus?

8. Symptoms of COVID-19?

9. Do you think home remedies help in control COVID-19?

10. Fever, Dry cough, difficulty in breathing - confirmatory symptoms for Corona ?

11. Is lockdown helps in controlling the spread of Corona?

12. Major cause for the fast spread of Corona?

13. Is there a treatment for Coronavirus?

14. Is there a Vaccine for Coronavirus?

15. Do you think using mask and hand wash hygiene helps in control COVID-19? 